\title{
PENDAPATAN USAHA TERNAK AYAM BROILER DI DESA KAPUH KECAMATAN SIMPUR KABUPATEN HULU SUNGAI SELATAN PROVINSI KALIMANTAN SELATAN
}

\author{
(Broiler Chicken Business Income In Kapuh Village Simpur Districts Hulu Sungai Selatan South \\ Kalimantan Province)
}

Bahrun dan Zuraida

Faculty of Agricultural, Achmad Yani Banjarmasin's University

Jln. Jendral A.Yani.km.5,5 Komplek Stadion Lambung Mangkurat Banjarmasin

Penulis koresponden : bahrun.bn@gmail.com

Article Submitted: $19-04-2021$

Article Accepted: 30-05-2021

\begin{abstract}
This research is technically aimed at knowing the economic operation of broiler chicken cultivation regarding costs, income and business income of broiler chickens in Kapuh Village. The method used in this research is descriptive qualitative research method. Determination of respondents was carried out by case method to 1 (one) farmer working on broiler chickens in Kapuh Village, Simpur District, Hulu Sungai Selatan Regency, South Kalimantan Province as respondent farmers. Broiler chicken farming which is carried out by an independent livestock business, the breeder provides himself with all the equipment and production inputs starting from the provision of land and cages, seeds to harvesting and selling. The explicit costs of animal husbandry include costs of production facilities, depreciation of tools and labor outside the family (TKLK) with an average of Rp. 79,900,000.00. The average production obtained was 4,004 heads or $6,406.40 \mathrm{~kg}$, while the price at the time of research / harvest was IDR 20,000 / kg. Receipt of Rp. 128,128,000.00 and an income of Rp. $43,503,500.00$
\end{abstract}

Keywords: breeders, cost, production, revenue, income

\section{PENDAHULUAN}

Ayam broiler termasuk jenis hewan ternak pada kelompok unggas sebagai salah satu penyedia sumber makanan, antara lain sebagai penyedia keperluan protein hewani. Budidaya ayam broiler juga bisa digunakan untuk komoditas usaha yang prospektif, karena dan dapat dimanfaatkan sebagai salah satu usaha yang cukup menguntungkan Suwarta, 2011)

Sebagai salah satu bagian dari sektor pertanian, sub sektor peternakan memiliki peran yang cukup penting untuk menopang perekonomian nasional. Kegiatan peternakan unggas di Indonesia dan cukup komponen usaha yang lengkap baik pada sektor hulu maupun pada sektor hilir.

Kegiatan pada usaha ternak dapat memberikan sumbangan yang nyata pada pelaksanaan pembangunan pertanian serta mempunyai nilai yang strategis, antara dapat mencukupi keperluan yang berasan dari protein hewani, dan dapat memberikan peluang kerja untuk masyarakat.

Pada kegiatan dan perkembangan usaha ternak ayam broiler, ditemui beberapa permasalahan diantaranya masih kurangnya modal, tidak menguasi teknologi, harga yang panen yang berubah-ubah (fluktuasi), kurangnya informasi pasar. Untuk mengatasi 
permasalah yang dihadapi tersebut, maka peternak ayam broiler dapat melakukan kerjasama atau bermitra dengan perusahaan ternak ayam broiler (Harianto dkk, 2019)

Pada kenyataannya daging ayam sudah menjadi salah satu primadona yang dikonsumsi masyarakat karena harganya yang cukup terjangkau bila dibandingkan mengkonsumsi daging sapi dan kambing. Hal ini dapat dimanfaatkan guna memacu peningkatan usaha peternakan terutama usaha ternak ayam broiler yang bermanfaat untuk memenuhi protein hewani dan dapat terjangkau untuk masyarakat sehingga konsumsi daging di Indonesia dapat meningkat (Nurdiana Mulyatini dkk, 2019)

Adapun kebutuhan akan pangan secara kualitatif maupun kuantitatif masih terus meningkat, sehinga perlu peningkatan ketersedian sumber gizi terutama protein hewan. Untuk memenuhi gizi tersebut maka diperlukan pengembangan usaha dibidang usaha ternak. Usaha ternak ayam broiler dapat menjadi alternatif guna mencukupi keperluan protein hewani untuk masyarakat, hal ini dimungkinkan sebab usaha ternak dalam waktu tidak begitu lama produksi dagingnya sudah bisa manfaatkan (Rasyaf.M, 2008).

Peternak yang melakukan usahanya sendiri, harus mempersiapkan ketersediaan input produksi dengan modal sendiri, hal lain peternak dapat melakukan pemasaran hasil panen ternaknya. Beberapa faktor yang memungkin dilaksanakannya ternak ayam broiler secara mandiri yaitu yaitu: pemeliharaannya cukup mudah, waktu pemeliharaannya cukup singkat, sistem kembalinya modal relatif cepat. Pada kegiatan usaha ternak ditemui beberapa kendala yaitu: sarana produksi ternak yang masih tidak terpenuhi , pengelolaan pemeliharaan yang dilakukan peternak yang belum memadai, masih terbatasnya modal, resiko terhadap keadaan pasar relatif tinggi, kegiatan usaha ternak melihat kondisi situasi dan tanpa bersifat spekulasi/untung- untungan (Hidayat dalam Egi Gifari Irhais dkk, 2019).

Mengingat ternak ayam broiler sebagai ternak yang banyak diusahakan, karena perkebangan dan pertumbuhan cepat bila dibandingkan dengan ternak lainnya. Kegiatan ternak ayam broiler dipanen pada saat ternak berumur 28-35 hari. Hal ini menyebabkan perputaran modal pada usaha peternakan ayam broiler sangat cepat, dan biaya yang dikeluarkan cepat kembali. Aktifitas usaha ternak ayam broiler bisa menjadi usaha yang cukup tepat untuk dikembangkan sangat potensial bagi masyarakat (Wulansari,dkk, 2018)

Berdasarkan hal tersebut kiranya perlu diadakan suatu penelitian usaha peternakan ayam broiler yaitu mengenai/meliputi pengelolaan ternak ayam, biaya dan pendapatan tersebut.

Secara teknis penelitian ini bertujuan mengetahui bagaimana penyelenggaraan usaha ternak ayam broiler, sedangkan secra ekonomis mengenai jumlah biaya yang diperlukan, berapa penerimaan dan pendapatan dari kegiatan usaha ternak ayam broiler di Desa Kapuh.

\section{METODE PENELITIAN}

\section{Penentuan Daerah Penelitian}

Pelaksanaan daerah penelitian di Desa Kapuh di Kecamatan Simpur Kabupaten Hulu Sungai Selatan Provinsi Kalimantan Selatan, yang dilaksanakan sejak bulan Oktober hingga Desember 2020, yaitu dari tahap persiapan sampai dengan penyusunan laporan.

\section{Pengumpulan Data.}

Semua data yang diperoleh dan digunakan untuk analisis terdiri dari data primer, yaitu data wawancara langsung kepada peternak, sedangkan data sekunder hasil dari bahan pustaka dan jurnal yang relevan dengan penelitian, 


\section{Teknik Penarikan Data.}

Metode yang digunakan dalam penelitian ini yaitu dengan metode penelitian deskriptif kualitatif. Sugiyono (2011), "menyatakan bahwa: penelitian kualitatif yaitu penelitian yang data dan hasil penelitian lebih berkenaan dengan interpretasi terhadap data yang ditemukan di lapangan".

Penentuan responden dilakukan secara metode kasus kepada 1 (satu) orang peternak yang mengusahakan ternak ayam broiler diwilayah penelitian sebagai responden.

\section{Teknik Analisis}

Setelah semua data yang diperoleh selanjutnya diolah, dianalisa yang berkenaan dengan: "biaya, penerimaan dan pendapatan" dari usaha ternak ayam btoler.

Untuk mengetahui jumlah
penerimaan secara numerik disusun sebagai berikut (A.Kasim, 1995) :

$\mathrm{TR}=\mathrm{P} \times \mathrm{Q}$

Keterangan :

$\mathrm{TR}=$ Penerimaan Total $/(\mathrm{Rp})$

$\mathrm{P}=\operatorname{Harga}(\mathrm{Rp} / \mathrm{kg})$

$\mathrm{Q}=$ Jumlah produksi $(\mathrm{kg})$

Jumlah pendapatan dapat diketahui dengan menggunan rumus (A. Kasim (1995) sebagai berikut :

$\mathrm{I}=\mathrm{TR}-\mathrm{TEC}$

Keterangan :

$\mathrm{I} \quad=$ Pendapatan $(\mathrm{Rp})$

$\mathrm{TR}=$ Jumlah Penerimaan $(\mathrm{Rp})$

TEC $=$ Total Biaya eksplisit $(\mathrm{Rp})$

\section{HASIL DAN PEMBAHASAN}

\section{Deskripsi Pola Usaha Peternakan} Ayam Broiler.

Kegiatan peternakan ayam broiler

di Desa Kapuh Kecamatan Simpur, merupakan pola mandiri.

Pola mandiri merupakan salah satu bentuk budidaya ayam broiler yang dilaksanakan peternak tanpa pendampingan/kerjaama dengan pihak lain, baik pemberian input, teknik berternak dan pemasaran".

Umur responden sangat berpengaruh terhadap kegiatan usaha ternak ayam broiler yang diselenggarakan, semakin tua umur responden, Umur responden yang menyelenggarakan usaha ternak ayam broiler yaitu 51 tahun dengan tingkat pendidikan SLTA dan jumlah tanggungan 4 orang anggota keluarga.

\section{Penyelenggaraan Usaha Ternak Ayam Broiler di Desa Kapuh \\ Pengadaan Bibit}

Setelah kandang dan alat perlengkapan siap, selanjutnya barulah pengadaan bibit yang digunakan para responeden berumur \pm 1 minggu. Bibit ayam broiler (DOC) dibeli dari perusahaan penyalur bibit. Bibitt ayam tersebut dikemas apik oleh perusahaan dalam kotak bibit yang digunakan sebesar 40 box atau 4.080 ekor.

\section{Keadaan Kandang}

Pada saat penelitian dilaksanakan, responden menggunakan kandang tipe panggung, lokasinya agak jauh dari pemukiman penduduk setempat, hal ini maksudkan untuk mengurangi permasalahan dan kesehatan ternak yang disebabkan oleh pencemaran dan terjangkitnya penyakit pada ayam.

Keperluan luas usaha ternak ayam sesuai dengan luas kandang yang digunakan. Jumlah kandang sebanyak 20 buah dengan ukuran rata-rata $6 \mathrm{~m} \mathrm{x}$ $10 \mathrm{~m}$

\section{Persiapan Kandang}

Sebelum bibit ayam broiler (DOC) tiba dilokasi yang telah dipersiapkan, seluruh kandang dan peralatan yang tersedia terlebih dahulu harus dibersihkan dengan air dengan cara disemprot, selanjutnya disikat/doiosok hingga bersih dari 
kotoran yang melekat dan dibiarkan sampai keesokannya harinya

\section{Pemberian Pakan}

Pakan yang tepat serta cukup mengandung uusur-unsur yang diperlukan bagi perturnbuhan ayarn sangat besar pengaruhnya maka hal ini perlu diperhatikan. Untuk pernberian pakan pada bibit ayam umur 1 - 17 hari dapat menggunakan kotak bekas anak ayam dan dilakukan secara bertahap artinya sedikit tetapi sering, baik dilakukan pada pagi, siang dan pada sore hari.

Berdasarkan hasil penelitian Achmad Jaelani dkk (2013), pakan yang digunakan cukup mirip, khususnya pakan BR 1 untuk pakan starter dan BR 2 untuk pakan finisher.

Hasil penelitian dilapangan, Jenis pakan yang diberikan disesuaikan dengan keperluan ayam broiler. Adapun jenis pakan yang diberikan dengan kode BR-1 dan BR2. Jumlah pakan BR-1 yang diberikan ratarata sebesar $2.800 \mathrm{~kg}$ atau sebesar 56 sak, sedangkan jumlah pakan BR-2 yang diberikan rata-rata sebesar $3.200 \mathrm{~kg}$ atau sebesar 64 sak

\section{Pemberian Air Minum dan Pengobatan (vaksinasi)}

Pada saat bibit broiler (DOC) baru tiba dan sudah diletakan dalam kandang induk buatan pertama kali langsung diberikan minuman air hangat. Hal ini penting untuk menjaga stamina ayam. Untuk hari-hari berikutnya yaitu hingga 17 hari minuman diberikan lebih intensif dengan campuran vitamin, vaksin dan obat dalam tempat minum kecil yang sesuai dengan postur tubuh ayam. Untuk selanjutnya pemberian vitamin-vitamin, vaksin dan obat-obatan. Pemberiannya lebih ditekankan jika diindikasikan kurang baik maupun dengan situasi dan kondisi yang tidak memungkinkan.
Kebutuhan vaksinasi biasanya dilakukan pada umur 4 hari terhadap penyakit (tetelo), pada umur 7 hari terhadap penyakit cacar dan dilakukan vaksinasi ulangan terhadap penyakit tetelo pada umur 28 hari. Pada kondisi normal untuk pencegahan terhadap hama penyak it dan pertumbuhannya, saat ayam berumur 19 hari hingga panen dalam minuman diberikan campuran vitamin, antibiotik maupun vaksin secara berkelanjutan dan terarur dengan tepat waktu, tepat dosis ser ta tepat cara. Adapun jenis vaksin dan obatan yang diberikan meliputi Vetachit dengan penggunaan rata-rata sebesar 800 gram , Neo Meditril dengan penggunaan ratarata sebesar 2 liter dan Fortivit dengan penggunaan rata-rata sebesar 2 liter.

\section{Panen}

Pada saat ayam masih berumur muda biasanya telah ada pelangganpelanggan tetap maupun pelanggan baru untuk memesan untuk membelinyajika umur ayam tersebut telah siap panen. Ayam siap dipasarkan yaitu pada sekitar umur 38-40 hari dengan kesepakatan harga dari kedua belah pihak.

\section{Produksi}

Menurut Egi Gifari Irhais $d k k$ 2019), bobot panen pada ayam broler yaitu rata-rata $1,5 \mathrm{~kg} / \mathrm{ekor}$ Produksi yang diperoleh dari usaha ayam broiler berat badan rata-rata 1,6 kg/ekor. Dari rata-rata usaha ternak ayam sebesar 4.080 ekor dengan tingkat kematian rata-rata sebesar 76 ekor $(0,54 \%)$, maka rata-rata produksi yang diperoleh adalah sebesar 4.004 ekor atau $6.406,40 \mathrm{~kg}$ (6,41 ton). Rata-rata jumlah produksi usaha ternak ayam broiler (Tabel 1). 
Tabel 1. Rerata Produksi Pada Ternak Ayam Broiler

\begin{tabular}{llrrr}
\hline No & \multicolumn{3}{c}{ Jumlah produksi } & \multicolumn{1}{c}{ Persentase } \\
\cline { 2 - 4 } & & (ekor) & \multicolumn{1}{c}{$(\mathrm{kg})$} & \multicolumn{1}{c}{ ) } \\
\hline 1 & Hidup & 4.004 & $6.406,40$ & 09,46 \\
2 & Mati & 76 & 121,60 & 0,54 \\
\hline & Jumlah & 4.080 & $6.528,00$ & 100,00 \\
\hline
\end{tabular}

Sumber: Analisa dari Data Primer.

\section{Biaya Eksplisit}

Pengeluaran yang dibagikan oleh responden dalam kegiatan usaha ayam broiler secara nyata dikeluarkan, antara lain biaya pembuatan sarana produksi ternak, penyusutan peralatan dan penggunaan tenaga kerja di luar keluarga (TKLK). Biaya yang digunakan sebesar Rp. 84.624.500,00-

\section{Sarana Produksi}

Biaya sarana produksi yang dikeluarkan dalam kegiatan usaha ternak ayam kampung broiler meliputi biaya penggunaan bibit, pakan, obatobatan dan kapur. Total biaya sarana produksi sebesar Rp. 79.900.000,00. Data dapat dilihat pada Tabel 2.

Tabel 2. Rerata Fasiltas Produksi Ayam Broiler

\begin{tabular}{clrc}
\hline No & \multicolumn{1}{c}{ Sarana Produksi } & Rata-Rata $(\mathrm{Rp})$ & Persentase $(\%)$ \\
\hline 1. & Bibit & $30.000 .000,00$ & 37,55 \\
2. & Pakan & $22.120 .000,00$ & 27,68 \\
& - BR-I & $25.280 .000,00$ & 31,64 \\
& - BR-2 & & \\
3 & Obat-obatan : & $120.000,00$ & 0,15 \\
& - Vetachit & $680.000,00$ & 0,85 \\
& - Neo Meditril & $1.200 .000,00$ & 1,50 \\
& - Fortivit & $500.000,00$ & 0,63 \\
4 & Kapur & $79.900 .000,00$ & 100,00 \\
\hline
\end{tabular}

Sumber : Analisa dari Data Primer

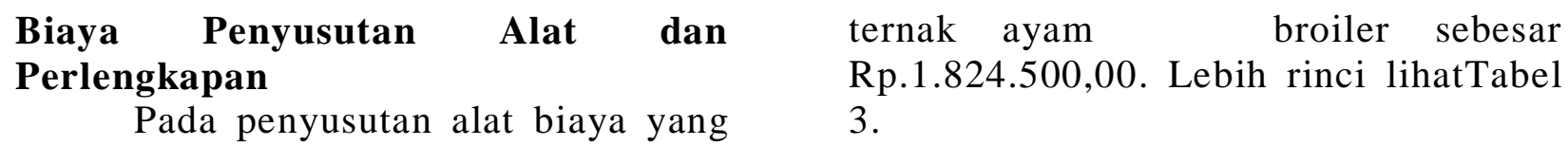
dikeluarkan dalam kegiatan usaha

Tabel 3. Rerata Biaya Penyusutan Alat Pada Ternak Broiler

\begin{tabular}{clrr}
\hline No & \multicolumn{1}{c}{ Alat } & Jumlah $(\mathrm{Rp})$ & Persentase $(\%)$ \\
\hline 1. & Kandang ayam & $1.200 .000,00$ & 65,77 \\
2. & Tempat minum & $22.500,00$ & 1,23 \\
3. & Tempat Makan & $50.000,00$ & 2,74 \\
4. & Lampu & $102.000,00$ & 5,59 \\
5. & Lilstrik & $450.000,00$ & 24,66 \\
\hline & Jumlah & $1.824 .500,00$ & 100,00 \\
\hline
\end{tabular}

Sumber : Pengolahan Data Primer Tahun 2020 
Biaya Tenaga Kerja Luar Keluarga

Untuk elaksanakan kegiatan

Usaha tentunya diperlukan tenaga kerja, "baik tenaga kerja upahan maupun tenaga kerja dalam keluarga". Kegiatan yang dilakukan oleh tenaga kerja luar keluarga (TKLK) dalam kegiatan usaha ternak ayam broiler adalah pemberian obat-obatan, pembersihan kandang dan panen. Ratarata biaya tenaga kerja luar keluarga (TKLK) dalam kegiatan usaha ternak ayam broiler yaitu sebesar Rp.2.900.000,00. Data lebih rinci lihat Tabel 4.

Tabel 4. Rata-rata Biaya Biaya Tenaga Kerja diLuar Keluarga

\begin{tabular}{clcc}
\hline No & \multicolumn{1}{c}{ Jenis Kegiatan } & Jumlah (Rp) & Persentase (\%) \\
\hline 1 & Pembersihan kandang & $1.500 .000,00$ & 51,72 \\
2 & Panen. & $1.400 .000,00$ & 48,28 \\
\hline & Jumlah & $2.900 .000,00$ & 100,00 \\
\hline
\end{tabular}

Sumber: Analisa dari Data Primer

Berdasarkan data pada tersebut diatas makan dapat diketahui jumlah besarnya biasa eksplisit yang dikeluarkan oleh responden selama kegiatan usata ternak ayam broiler yaitu sebesar Rp. 84.624.500,00. Data lebih rinci dapat dilihat pada Tabel 5.

Tabel 5. Biaya Eksplisit Pada Usaha Ternak Ayam Broiler

\begin{tabular}{clrc}
\hline No & \multicolumn{1}{c}{ Jenis Kegiatan } & Jumlah (Rp) & Persentase (\%) \\
\hline 1. & Saprodi & $79.900 .000,00$ & 94,42 \\
2. & Penyusutan Alat dan Perlengkapan & $1.824 .500,00$ & 2,16 \\
3. & Tenaga Kerja Luar Keluarga (TKLK) & $2.900 .000,00$ & 3,43 \\
\hline & Jumlah & $84.624 .500,00$ & 100,00 \\
\hline
\end{tabular}

Sumber : Analisa dari Data Primer

\section{Penerimaan (TR).}

Penerimaan adalah perakalian produksi dengan harga saat penelitian. Dari analisa dengan penerimaan Rp. 128.128.000,00. (Tabel 6).

Tabel 6. Rerata Jumlah Produksi dan Penerimaan Dalam Usaha Ternak Ayam Broiler

\begin{tabular}{|c|c|c|c|}
\hline \multicolumn{2}{|c|}{ Jumlah produksi } & \multirow{2}{*}{$\begin{array}{c}\text { Harga } \\
(\mathrm{Rp} / \mathrm{kg})\end{array}$} & \multirow{2}{*}{$\begin{array}{c}\text { Penerimaan } \\
(\mathrm{Rp})\end{array}$} \\
\hline (ekor) & $(\mathrm{kg})$ & & \\
\hline 4.004 & $6.406,40$ & $20.000,00$ & $128.128 .000,00$ \\
\hline
\end{tabular}

Sumber : Analisa dari Data Primer

\section{Pendapatan.}

Dengan peneriman Rp.

128.128.000,00 dan biaya yang dikeluarkan
Rp. 84.624.500,00. Jumlah yang diperoleh pada usaha ternak pendapatan sebesar Rp. 43.503.500,00. (Tabel 7). 
Tabel 7. Rerata Penerimaan, Biaya Eksplisit dan Pendapatan Pada Usaha Ternak Ayam Broiler

\begin{tabular}{ccc}
\hline $\begin{array}{c}\text { Penerimaan } \\
(\mathrm{Rp})\end{array}$ & $\begin{array}{c}\text { Total Biaya Eksplisit } \\
(\mathrm{Rp})\end{array}$ & $\begin{array}{c}\text { Pendapatan } \\
(\mathrm{Rp})\end{array}$ \\
\hline $128.128 .000,00$ & $84.624 .500,00$ & $43.503 .500,00$ \\
\hline
\end{tabular}

Sumber : Analisa dari Data Primer

Berdasarkan keterangan pada Tabel 7, pendapatan responden sebesar Rp. 43.503.500,00, maka bila dibagi dengan lamanya kegiatan usaha ayam broiler ( 2 bulan), diperoleh rata-rata. pendapatan sebesar Rp.21.751.750/bulan dan apabila pendapatan tersebut dibagi dengan jumlah tanggungan keluarga dan peternak (5 orang) maka rata-rata pendapatan sebesar Rp. 4.350.350,0.

Bila pendapatan tersebut dibaningkan dengan "Upah Minimum Provinsi (UMP) Kalimantan Selatan" sebesar Rp. 2.877.447 / bulan. Maka perolehan pendapatan usaha ternak perlu menjadi perhatian dan dimungkinkan usaha tersebut untuk terus dikembangkan.

\section{KESIMPULAN DAN SARAN}

\section{Kesimpulan.}

1. Usaha ternak ayam broiler yang dilaksanakan bersifat mandiri, peternak menyediakan sendiri seluruh perlengkapan, dan input produksi (penyediaan lahan ternak dan kandang, bibit sampai proeses panen dan penjulan.

2. Biaya sarana produksi, penyusutan alat dan tenaga kerja luar keluarga. (Biaya Eksplisit). sebesar Rp. 79.900.000,00.

3. Produksi yang diperoleh rata-rata sebesar 4.004 ekor atau sebesar $6.406,40 \mathrm{~kg}$ sedangkan harga pada saat penelitian/panen sebesar Rp.20.000/kg. Penerimaan sebesar Rp. 128.128.000,00 dan pendapatan sebesar Rp. 43.503.500,00

\section{Saran-saran}

1. Untuk meingkatkan pendapatan hendaknya lebih diperhatikan dalam pengelolaan usaha ternak ayam broiler yang diusahakan terutama yang berhubungan dengan sarana produksi (terutama pakan) yang sangat berpengaruh terhadap biaya produksi.

2. Perlu adanya bantuan dari pemerintah/instansi terkait dalam hal perbaikan teknik usaha ternak ayam broiler agar diperoleh produksi yang optimal.

3. Untuk menjaga kestabilan dan kepastian harga jual ayam broiler, agar peternak tidak mengalami kerugian, maka sangat diperlukan peran pemerintah atau dinas terkait dalam mengatur harga hasil panen, pakan dan obat-obatan ternak .

\section{DAFTAR PUSTAKA}

Achmad Jaelani. Suslinawati dan Maslan. 2013, "Analisis Kelayakan Usaha Peternakan Ayam Broiler di Kecamatan Tapin Utara Kabupaten Tapin”. Jurnal Ilmu Ternak. Volume 13.nomor 2 Desember 2013.

Liptan, 1984. Beternak Ayam Ras. Balai Informasi Pertanian Kalimantan Selatan

Boediono, 1989. "Ekonomi Mikro. Penerbit BPEE. Jakarta.

Ferry Tamailudin, 2014 "Panduan lengkap ayam broiler:.. Penebar swadaya. Jakarta

Harianto, Putri Suci Asriani, Nyayu Neti Arianti, 2019. "Perbandingan", Pendapatan dan Efisiensi Usaha 
Peternakan Ayam Potong Pada Berbagai Pola Usaha Di Kabupaten Bengkulu Utara- Agric jurnal. Vol. 31, No. 2, Desember 2019:

Hidayati (dalam) Egi Gifari Irhais, TendyKusmayadi dan Vela Rostwentivaivi.S. 2019. JANHUS, Journal "of Animal Husbandy Science (Analysis Feasibility Enterprise Development of Farmer Broiler Independent Paterm in Garut)" Jurnal Ilmu Peternakan. Fakultas Pertanian. Garut. ISSN ; 2548-7914.

Mubyarto, 1989, "Pengantar Ekonomi Pertanian, Lembaga Penelitian Pendidikan, Penerangan Ekonomi dan Sosial (LP3ES). Jakarta.

Murti, Ariani Trisna and Suroto, Karunia Setyowati and Karamina, Hidayati (2020) Analisa Keuntungan Usaha Peternakan Ayam Broiler Pola Mandiri Di Kabupaten Malang (Studi Kasus Di Kecamatan Karangploso Kabupaten Malang)- Jurnal. SOCA: Jurnal Sosial Ekonomi Pertanian, 14 (1). pp. 40-54. ISSN 2615-6628

Nurdiana Mulyani, Ratih Sri Y, dan Elin Herlina. 2019. "Rantai pasokan dalam menongkatkan ,pendapatan peternak ayam potong. Jurnal ekonologi ilmu manajemen. Volume 6 no. 1 April 2019. P-ISSN 2355-6099 e-ISSN 2620-6188.

Rasyaf. M, 1983. "Panduan Beternak Ayam Pedaging" (edisi revisi). Penebar swadaya. Jakarta.

Ridha Yatni, Rachmat Pambudy, Burhanuddin Burhanuddin.Pengaruh Kewirausahaan Terhadap Pertumbuhan Usaha Peternakan
Ayam Broiler Pola Mandiri di Kabupaten Lima Puluh Kota Jurnal Ilmu dan Teknologi Peernakan Tropis (Jitro) p. ISSN:2406-7489 e.ISSN:2406-9337 Vol 6, No 3 (2019)

Saelindra, 2017, Budidaya Ayam Potong: Peluang Usaha Unggulan. Zahara Pustaka. Jakarta. SBN: 978-6021624-13-5

Sugiyono. 2011, "Metode Penelitian Kualitatif dan R \& D", Penerbit Alfa Beta. Bandung

Suwarta. Irham dan Hartono.S. 2012, "Struktur Biaya dan Pendapatan Usaha Ternak Ayam Broiler diKabupaten Sleman" .Jurnal Agrika. Vol.6 No.1 mei 2012.

Syarifuddin A. Kasim. 1995, Pengantar Eknomi Produksi Pertanian. Universitas Lambung Mangkurat.. Banjarbaru.

Uwarta, Suwarta; IRHAM, Irham; Hartono, Slamet. Efektifitas Pola Kemitraan Inti-Plasma Dan Produktifitas, Usaha Ternak Ayam Broiler Peternak Plasma Dan Mandiri Serta Faktor Yang Mempengaruhi di Kabupaten Sleman. JSEP (Journal of Social and Agricultural Economics), [S.1.], v. 4, n. 1 , p. 53-62, mar. 2010. ISSN 23562382

Wulansari.P.K.P.IW. Sukanata dan I.M.Suasta. $2018 . \quad$ "Analisis Pendapatan Peternakan Ayam Broiler dengan Sistem Kandang Tertutup (Closed House): Pada Pola Mandiri (Studi Kasus) pada CV Sari Mulya di desa Tunjuk Tabanan). E-Jornal Peternakan 